\title{
Integrated Urban Stormwater Management and Planning for New Township Development in Malaysia
}

\author{
Chun Kiat Chang ${ }^{1, a}$, Nor Azazi Zakaria ${ }^{1}$ and Mohd Radzman Othman ${ }^{2}$ \\ ${ }^{1}$ River Engineering and Urban Drainage Research Centre (REDAC), Universiti Sains Malaysia, Nibong Tebal, Penang, Malaysia \\ ${ }^{2}$ Kwasa Land Sdn. Bhd., Lot 116, Jalan Hevea, RRIM, Sungai Buloh, Selangor, Malaysia
}

\begin{abstract}
The on-going Kwasa Damansara Township development is aspire to be a township development with an initiative to unlock the land value and spur development in the region, and demands a high quality built environment. The township development strategy has considered a number of sustainable elements such as landscape and ecology, water, waste, green infrastructure, green buildings, green mobility and green energy. The key design objective for the proposed development is to create a new focal point that reflects the township of a 21st Century; one that is green, connected and has a sense of place making. The Urban Design Guidelines was prepared to guide and assist all the stakeholder contribution towards a well coordinated development and high quality public realm and build environment. In doing so, one of the initiatives was to formulate the long term solution for the flooding, drainage and stormwater related issues by urban stormwater management. By integrating stormwater management planning with landscape and environmental planning, it will add aesthetic and recreational values to the water amenities. The township development is planned to become a showpiece of the urban stormwater management for the region.
\end{abstract}

\section{INTRODUCTION}

Conventional stormwater system has long been in practice in Malaysia which adopts the rapid disposal, localised, reactive, and mono-functional drainage concepts. This approach has traditionally been focused on managing flood impacts based on a conveyanceoriented approach. The introduction of Urban Stormwater Management Manual for Malaysia, or MSMA [1, 2], changed the stormwater management landscape in the country. However, with the increasing need to meet demands for green technologies and arrest climate change, stormwater engineers are facing a stiffer challenge to produce effective and sustainable urban drainage system. This requires the need to inject new technologies or innovation into the design of stormwater facilities.

The integrated stormwater management concept was fully adopted in formulating Stormwater Drainage Master Plan for the township development and comply MSMA. The Kwasa Damansara Township (Figure 1) is planned to become a showpiece of the new concept of urban stormwater management for the region. Emphasis is on the necessity of the use of MSMA in all stormwater system design and implementation in order to protect the environment of the surrounding areas.

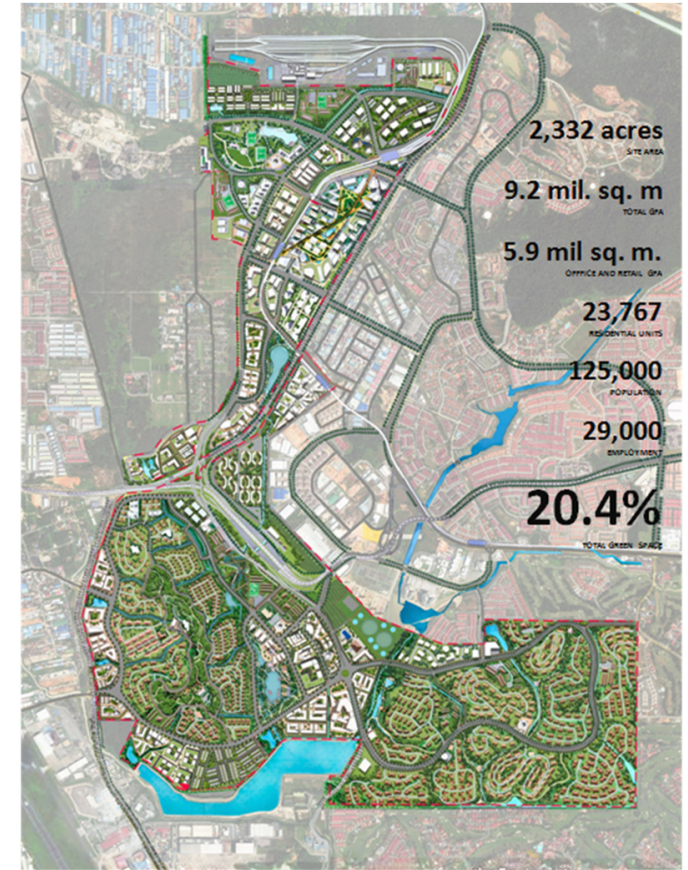

Figure 1. Kwasa Damansara Township

\section{Project Background}

The Kwasa Damansara new township is a master development project to be carried out on approximately 2332 acres of land in Selangor, Malaysia (Figure 1), where the land formerly belongs to Malaysia Rubber Research Institute (LGM) with works has been

\footnotetext{
a Corresponding author: redac10@usm.my
} 
commence in 2013. The township lies between two major cities; Petaling Jaya approximately $10.7 \mathrm{~km}$ southeast and Shah Alam about $11.6 \mathrm{~km}$ southwest. Spanning across the northern zone of Greater Klang Valley would enhance the possibility of escalating land values of the township. The Kwasa Damansara Township is also strategically sited with high accessibility to major highways such as the North-South Highway, Damansara-Puchong Highway, Guthrie Highway and North Klang Valley Expressway (Figure 2).

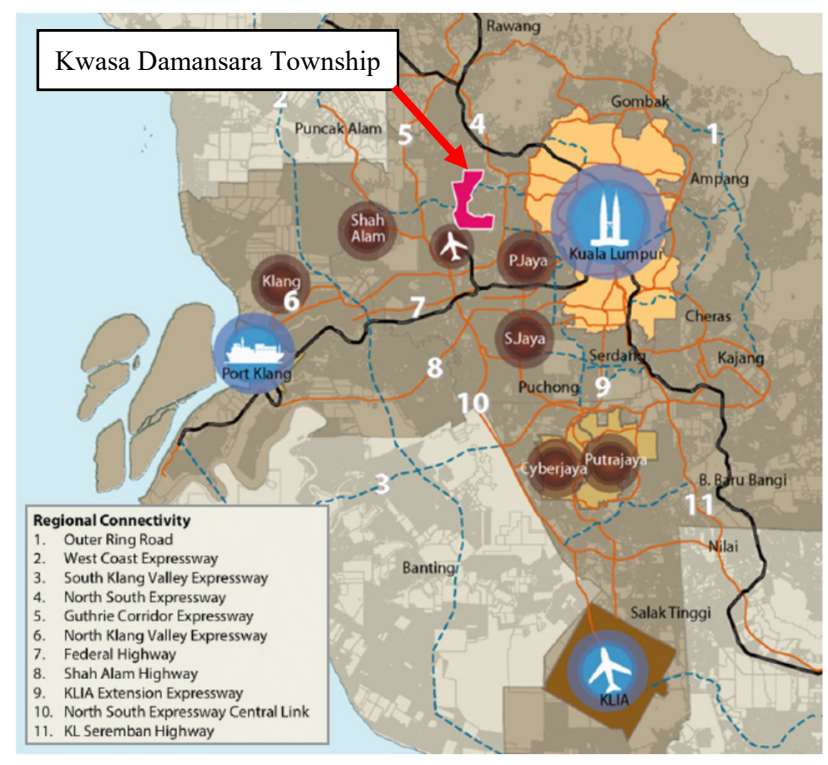

Figure 2. Project area

Kwasa Damansara Township master developer model is a unique development implementation model that ensures the master developer has a take in the developments of the sub-parcels, envisages joint developments with potential and qualified developers at various stages and phases. The township master plan is designed with extended flexibility to development products whilst offering sufficient control in achieving a cohesive and integrated development. The Master Developer prepares the Master Plan for the overall township development which utilized as the main instrument of reference to oversee the entire development and indicates the proposed sub development parcel with its intended land use and development intensity. These sub parcels are soon jointly developed. Urban Design Guidelines (UDGs) guides the development towards quality built environment and conformity of co-developers.

At implementation stage, the master developer will continue to exercise its responsibility in the following aspects:

a. Construct and deliver Level 1's infrastructure according to planning and technical requirements such as main infrastructure, utilities and township public open space

b. Provide required plots meant for Level 1's public facilities.

Level 1's infrastructure encompasses all incoming utilities and services directly from the service provided and will be laid up to the boundary of each sub development parcel. These include road, drainage, water, power, sewerage and telecommunication (Table 1). Whilst, Level 1's public amenities are intended to serve the township level's catchment or multiple neighborhoods within the 10,000 population threshold. The Master Developer will provide plot/sites to accommodate these amenities (such as community centre, schools, etc) which will subsequently be surrendered to the relevant authorities. Finally, the sub-parcel developers are responsible to developing Level 2's infrastructure and public facilities, intended to serve the local community and will be located within the subdevelopment's parcel.

Table 1. Level 1's infrastructure.

\begin{tabular}{|l|l|}
\hline \multicolumn{1}{|c|}{ Items } & \multicolumn{1}{c|}{ Components } \\
\hline Road & Major trunk road \\
\hline Drainage & $\begin{array}{l}\text { Road side drain, main drain, } \\
\text { detention pond, river }\end{array}$ \\
\hline Water & $\begin{array}{l}\text { Water tank, reticulation pipe and } \\
\text { pump house }\end{array}$ \\
\hline Power & Phasor measurement unit (PMU) \\
\hline Sewerage & $\begin{array}{l}\text { Treatment plant, reticulation } \\
\text { pipe and pump station }\end{array}$ \\
\hline Telecommunication & Utility site \\
\hline
\end{tabular}

\section{Concept of Integrated Stormwater Management}

In Kwasa Damansara township development, both planning and designing of the project land is subject to mandatory planning compliance of the local authority. The integrated stormwater management concept had fully adopted in formulating Stormwater Master Plan for the township development and comply MSMA. Emphasis has been stressed on the necessity of the use of MSMA in all drainage design and implementation in order to protect the environmental of the surrounding areas. These integrated stormwater master plan development is a master aims to address stormwater related issues and problems in surrounding areas and set to undergo land use transformation from agriculture to residential, commercial and industrial area as planned. The proposed drainage system which is known as sustainable urban drainage system (SUDs) is consistent with objectives of new stormwater management approach which focus on the both the quantity and quality control of urban runoff. One of the such system is Bio-Ecological Drainage System (BIOECODS), developed by River Engineering and Urban Drainage Research Centre (REDAC), Universiti Sains Malaysia [3-7]. This has been embodied in the concept of ecologically sustainable development which is aimed at ensuring that development can occur without long-term degradation of natural resources and the environment.

\subsection{Design Requirements and Approaches}


The integrated stormwater management concept has been embodied in the concept of ecologically sustainable solution to the flooding and pollution problems using the "control at source" and "treatment train" approach, as well as aimed at ensuring that development can occur without long-term degradation of natural resources and the environment.

\subsubsection{Control at Source}

Urbanisation of a catchment will always increase the quantity of stormwater runoff. The level of runoff quantity control required is dependent on the type of development proposed, new development or redevelopment. Under the implementation of DID manual [8] and MSMA [1, 2], it was expected that there shall be no increase in flood discharge and frequency to the downstream catchments resulting from to the urban development. Flow control requirements are stipulated as the following [2]: Runoff quantity control requirements for any size of development or redevelopment project is "Post development peak flow of any ARI at the project outlet must be less than or equal to the pre-development peak flow of the corresponding ARI $\left(Q_{\text {post }} \leq Q_{\text {pre }}\right)$ ". Direct discharge without control (rapid disposal) from the sub-development to the drain systems or waterways is not permitted. Such high peak discharge was to be reduced by introducing control-atsource facilities such as detention ponds and on-site detentions at strategic locations before it discharges into the river.

\subsubsection{Stormwater treatment train}

The stormwater treatment train represents an ecological approach to stormwater management and has proven effective and versatile in its various applications. The stormwater treatment train was designed with sequential components that contribute to the treatment of stormwater, by minimise the amount of pollution entering the downstream waterways. The components of the stormwater treatment train system were designed to treat stormwater runoff for water quality benefits and to reduce stormwater runoff peaks and volumes. This alternative approach to stormwater management not only has the potential to reduce infrastructure costs, but it also reduces maintenance costs. In addition, there is also a substantial benefit to downstream catchments. By treating stormwater where it falls on the land, responsible landowners are reducing their contribution to downstream flooding and sedimentation.

\subsubsection{Green Density}

Kwasa Damansara's sustainable agenda is structured by Malaysia's aspiration for reduction of carbon emission and develop low carbon cities. Realizing this, Kwasa Damansara, as like any other part of the world has embraced sustainability as an important feature for master planning. These include implementation of green infrastructure and also provision of green areas (open space and parks) as part of low carbon city initiative. Different hierarchies of green spaces are allocated to cater to various needs of recreation, education, leisure, communal space and nature appreciation to ensure the development becomes a low carbon emission development and thus meeting the national agenda of reducing $40 \%$ of carbon emission per GDP by 2020 .

\section{Development of Integrated Stormwater Master Plan}

The objectives of the proposed integrated stormwater master plan preparation are:

- to formulate long term solution for the flooding, drainage and stormwater management problems in the existing built-up areas in order to reduce the adverse effects of flooding on people and property and to protect the existing and proposed development by implementation of an integrated stormwater management plan by providing an appropriate level of flood protection to community expectations.

- to collect and convey stormwater from a catchment to its receiving water with minimal impact by managing and improving the quality of stormwater runoff from urbanized catchment and its pollution loads.

- to protect and enhance the natural waterdependent ecosystems and enhance community access to and enjoyment of water courses environments and to protect and maintain river environments to a high environmental and aesthetic quality while promoting sustainable recreational opportunities, community health, aesthetics amenity and healthy environment.

\subsection{Formulation of Stormwater Master Plan}

The proposed new township development is located on a medium hilly to low valley site (Figure 3) with the lowest level of natural waterway at $9.00 \mathrm{mIL}$ and highest points ranging from around $67 \mathrm{~m}$ to $119 \mathrm{~m}$ peak points. With the development area geographically divided into north and south catchments by the major regional road network. The range of existing ground level for northern catchment is between $28 \mathrm{~m}$ to $54 \mathrm{~m}$ and between $10 \mathrm{~m}$ to $119 \mathrm{~m}$ for southern catchment. As the project area is previously former owned by Malaysia Rubber Research Institute, it is therefore remaining as agriculture landuse, i.e. rubber tree plantation (Figure 4).

The details of post-development catchment for the Kwasa Damansara township development is shown Figure 5. The Level 1's infrastructure are plan and design based on the integrated stormwater master plan concept to conform to natural drainage patterns and discharge to natural drainage paths within a catchment. In general, runoff from development sites within a catchment should be discharged at the existing natural drainage outlet. Diverting runoff from other catchments or sub-catchments can cause adverse impacts on downstream properties and stormwater systems due to greater runoff volumes than would otherwise occur from the natural drainage catchment. Therefore, the diversion 
of runoff to or from other catchments or sub-catchments is not permitted without authority approval [2].

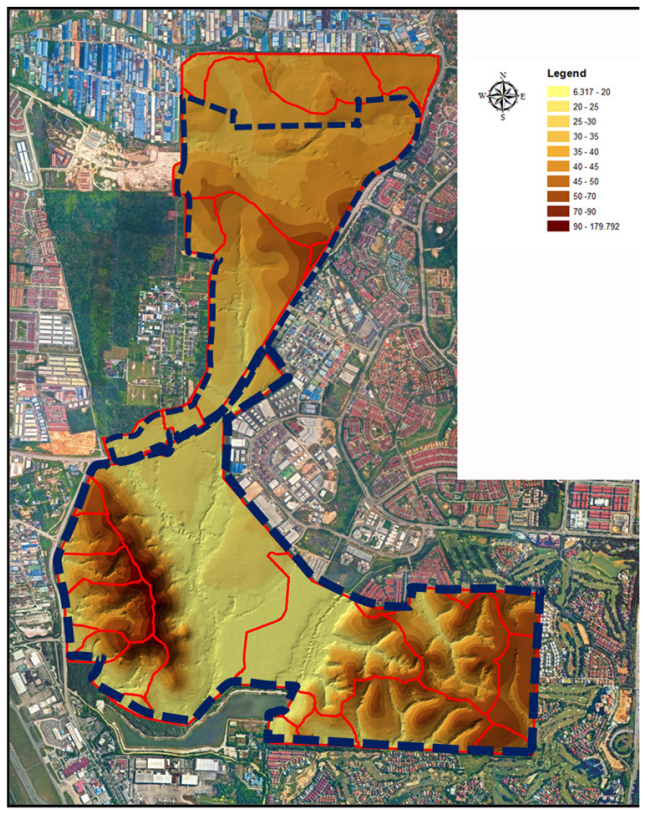

Figure 3. Pre-development catchment

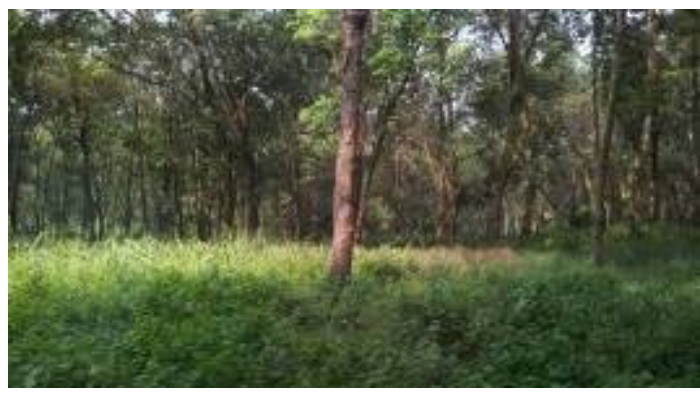

Figure 4. Rubber tree plantation at project area

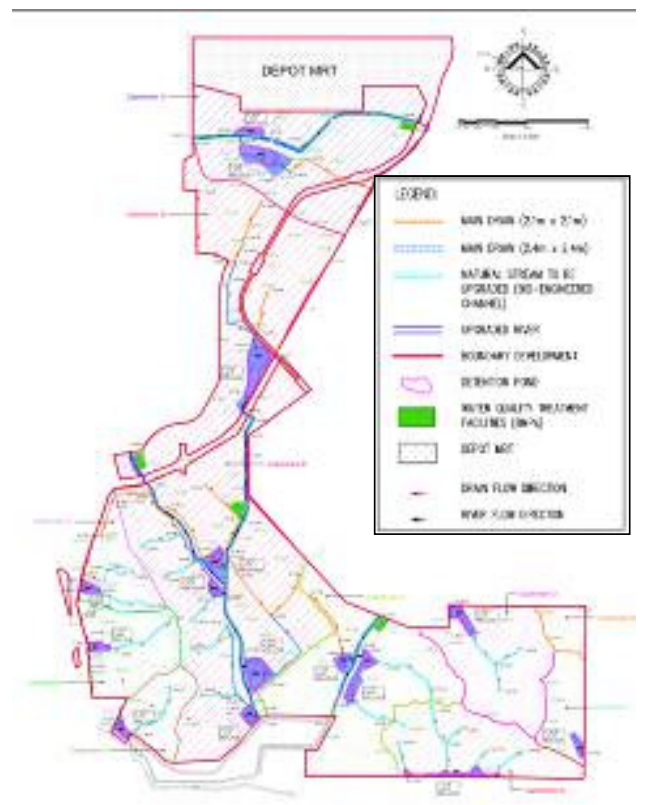

Figure 5. Post-development catchment

\subsection{Stormwater System}

Stormwater systems are divided into two categories: major system and minor system. The minor and major systems are closely interrelated, and the design of each component must be done in conjunction with the overall stormwater management standards set by the authorities [9]. Design storm annual recurrent interval (ARI) was adopted for the planning and design of minor and major storm runoff quantity systems shall be in accordance with Table 2 [2].

Table 2. Quantity Design Storm ARIs. [2]

\begin{tabular}{|l|c|c|}
\hline \multirow{2}{*}{ Type of Development * } & \multicolumn{2}{c|}{$\begin{array}{c}\text { Minimum } \\
\text { ARI** (year) }\end{array}$} \\
\cline { 2 - 3 } & $\begin{array}{c}\text { Minor } \\
\text { System }\end{array}$ & $\begin{array}{c}\text { Major } \\
\text { System }\end{array}$ \\
\hline Residential & & \\
Bungalow and semi-detached dwellings & 5 & 50 \\
Link house/apartment & 10 & 100 \\
Commercial and business center & 10 & 100 \\
Industry & 10 & 100 \\
Sport field, park and agricultural land & 2 & 20 \\
Infrastructure/utility & 5 & 100 \\
Institutional building/complex & 10 & 100 \\
\hline
\end{tabular}

Notes:

* For mixed developments, the highest of the applicable storm ARIs from the Table shall be adopted.

** Habitable floor levels of the buildings (platform levels) shall be set above the 100 year ARI flood level based on the most recent data available.

\subsubsection{Minor system}

The minor system is intended to collect, control and convey runoff from buildings, infrastructures and utilities in relatively frequent storm events to minimise inconvenience and nuisance flooding. Components in the minor system are sized to manage runoff generated by the more frequent short-duration storm events.

a. Road side drain - The roadside drain systems shall consist of either concealed concrete lined drain with inlets along road kerbs or ecological swale (Figure 6), which in line with the local council's minimum guidelines. A concealed system was chosen to allow the roadside kerbs to double as pedestrian walkway hence providing connectivity throughout the development. Ecological swale is a dual layer conveyance system (Figure 7) introduced to reduce the drainage footprint, as well as to provide additional water treatment. The surface layer resembles a grassed channel or a swale. Typical swale design, gentle side slope, low gradient and shallow depth applied to this layer. The underground layer, consist of a geosynthetic module enclosed in geotextile. It is connected to the surface layer via a layer of river sand or infiltration media. Ecological swale has the ability to reduce on-site peak flow rates by increasing the roughness of the channel and infiltration rates and also provide runoff quality treatment by removing low concentrations and quantities of TSS, heavy metals, hydrocarbons and nutrients from stormwater by means of sedimentation, filtration, soil absorption and plant uptake. In addition, ecological swale blends easily into 
their surrounding, adding considerably to the local amenity and/or local biodiversity [4].

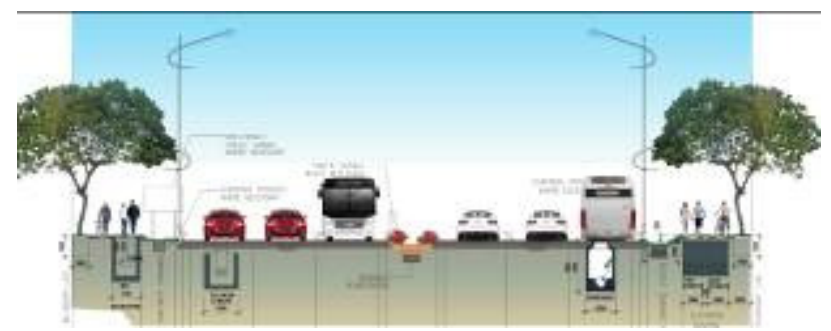

Figure 6. Typical road section and drainage system

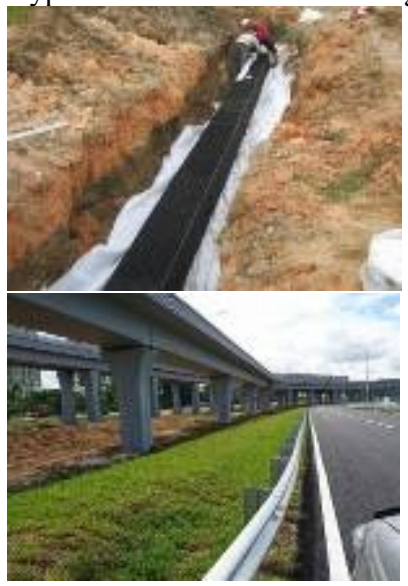

Figure 7. Ecological swale

b. On-site Detention (OSD) - In relation to the Kwasa Damansara integrated stomwater master plan design intent, the sub-parcel development Level 2's infrastructure design criteria shall be complied with the development guideline as specified in the UDGs. As direct discharge without control (rapid disposal) from the sub-parcel development to receiving water is not permitted, therefore it shall be temporarily stored in the OSD (for sub-parcel area development less than $10 \mathrm{ha}$ ). OSD is design for temporary storage and controlled release of stormwater generated within a site at a predetermined rate in accordance to the integrated stormwater master plan, whereby stormwater can be detained up to the certain maximum depth to reduce peak flows, achieve specific lag time for target design rainfall events. Figure 8 shows the example of underground OSD at a 'Park \& Ride' sub-parcel [10]. The below ground storage tank can be achieved with low maintenance, reducing peak flow, frees up space for landscaping and parking lots.
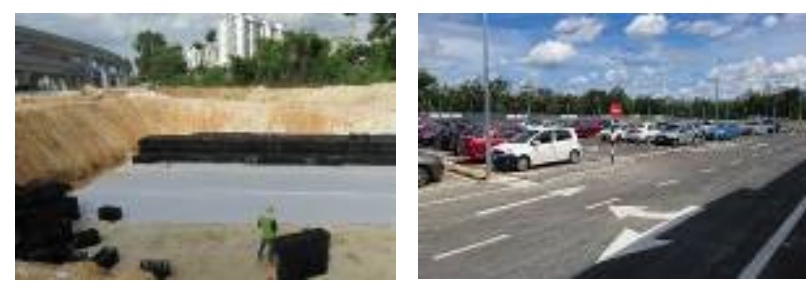

Figure 8. Example of below ground OSD storage tank at park and ride sub-parcel [10]
The major system is intended to safely convey and control runoff collected by the minor drainage system together with its possible overspill to the larger downstream systems and water bodies. Design criteria for the major quantity system are typically based on significant amounts of rainfall produced by the less frequent long-duration storms. The major system must protect the community from the consequences of large and reasonably rare storm events (up to 100-year ARI), which could cause severe property damage, injury or loss of life.

a. Main Drain - All roadside drains or discharge from each sub-parcel development shall flow into the downstream main drains where the runoff will be conveyed into a detention system downstream. The proposed main drains shall be covered box culvert (Figure 9). Primary treatment facilities such as gross pollutant traps (GPTs) required for the main drains will be considered as part of the control at source and treatment train. GPTs may be used as pre-treatment BMPs for flow into a pond or wetlands or to remove litter, debris, coarse sediment and hydrocarbon from stormwater.

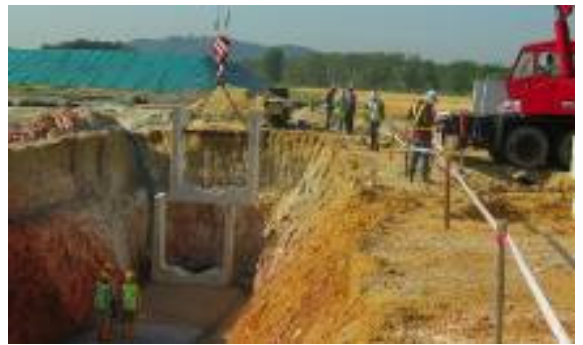

Figure 9. Installation of main drain at project site [10]

b. Engineered Channel - Engineered channel are part of the major drainage system designed to collect and convey flows from the minor drainage system and to provide for the safe passage of larger flows up to the major design storm. From a practical standpoint, as existing natural waterways within the project site shall be upgraded and not re-routed, the basic choice to be made initially is whether or not the waterway to be a hard-lined channel or bio-engineered channel for flow with higher velocities, as well as a grassed-lined or composite channel.

In order to increase the hydrological and ecological capacity of urban aquatic ecosystem to cope with impacts of township development, it is important to protect the project sites' ecology and develop sustainable solutions that shall contribute towards environmental quality by bringing back the stream/river to life. Therefore, bio-engineered channel is designed to ensure that the ecosystem values and functions are well preserved. The Bio-engineering technique is a softer and more pleasing alternative solution to the hard concrete lined channels due to its not only encourage the growth of a rich diversity of fishes and other aquatic life, but also improve the overall aesthetics of the channel and surrounding landscapes, as well as the quality of life for the human communities themselves. Vegetation planting consists of the installation of live grass and shrubs used to reduce surface erosion (Lacerda et al., 2004). In 
addition, bio-engineered channel is costs less to install compared to traditional infrastructure system and can be easily and quickly installed by site staff after undergoing training [12].
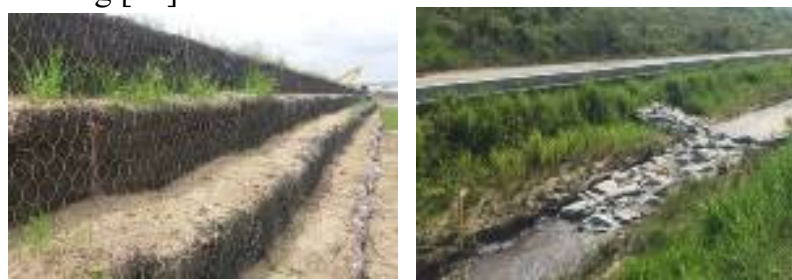

Figure 10. Example of bio-engineered channel using green terrawall system [12]

c. Community / Regional Storage - Community storage is a storage facility for sub-parcel developers (with area of development more than 10 ha) who are responsible in developing Level 2's infrastructure. In general, facilities such as detention ponds are used for controlling the increase in stormwater quantity resulting from larger urbanization. An overflow spillway set near the top of the embankment is required to safely discharge runoff that exceed the basin's discharge outlet capacity, to the main drain or river. Regional storage is a large community storage facilities constructed in public open space areas outside of private properties, or in conjunction with public recreation and sporting facilities at the lower end of catchments prior to discharge to receiving waters (river). It is suggested that all the inlets to the ponds shall have pre-treatment pollutant control facilities such as sediment forebay or other type of gross pollutant trap (GPTs'). They are primarily designed for attenuating runoff from developed areas through regulated outlet structures. The facility is typically designed to limit discharge to the pre-development stage, while storing water temporarily. The end product is expected to improve the aesthetic value for surrounding areas with the existence of the "Crystal Clear Blue Water Lake" at the most downstream end of the drainage system before discharging into rivers (Figure 11).

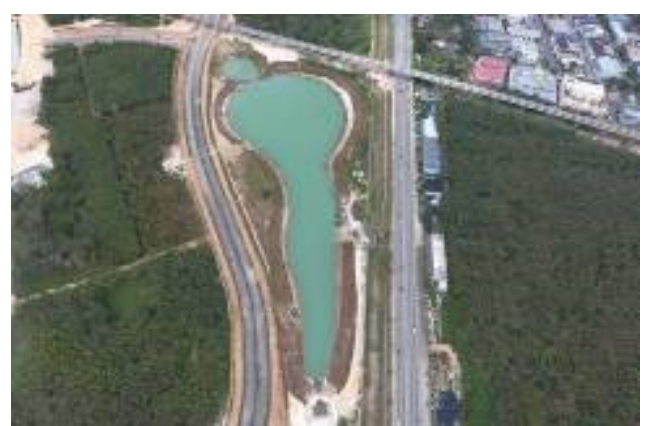

Figure 11. Detention pond with sediment forebay [10]

\subsubsection{River System}

There are several recognized river system within the development boundary, i.e. Kedondong River is the tributaries of Buloh River in north catchment, whilst Payung River, Paku River and Rumput River are among the three main tributaries for Damansara river in south catchment. Natural river should be confined to the low- flow section of the river, while the flood flow section to accommodate the designed flood discharges be confined to within the "river right-of-way". Whilst, a buffer area or such part of land adjacent to a river or water body that is designed or designated to remain in an undisturbed, natural state or any other circumstances determine with its distance or width must be provided. Under Kwasa Damansara township development, it is expected that there will be no increase in flood discharge and frequency due to the implementation of integrated stormwater management.

The river improvement works in the township development adopted the bio-engineering solution (Figure 12). The design approach had taken into account the dynamic equilibrium to set out a long term sustainable solutions for the river through river restoration measures including human-constructed meanders, floodplains, bank protection and stabilization techniques [12]. The buffer area has been developed for community usage such as bicycle path and walkway, as well as jogging track. As a result, the design approach improve the characteristic of the river by generating ecological value as well as a healthy community. In addition, such efforts will not only encourage the growth of a rich diversity of fishes and other aquatic life but also improve the overall aesthetics of the river and surrounding landscapes, as well as the quality of life for the human communities themselves.

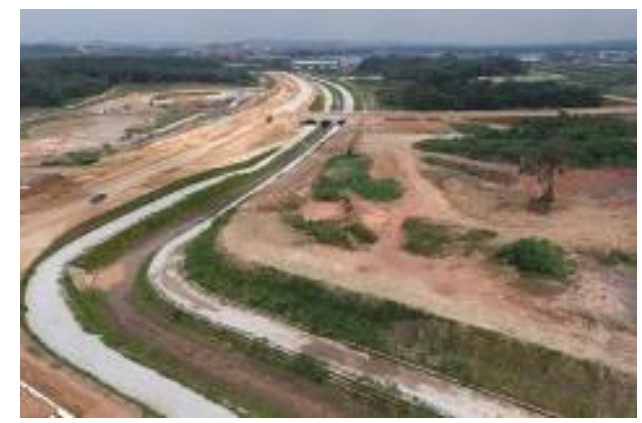

Figure 12. On-going river improvement works

\subsection{Green-Blue Corridor}

Kwasa Damansara is envisioned to be low carbon development to respond to the nation's aspiration for ensuring climate-resilient development for sustainability. Different hierarchies of green spaces are allocated to cater different kind of needs, thus the green spaces in Kwasa Land comprises of Town Park, Transit Park, Youth Park, Green Park, Central Park, Hill Park, corporate Park, Wetland and Neighbourhood Park. Whilst, blue corridor is part of the natural elements on site and is included to enhance the bio-diversity of the area. Overall, it will enhance the urban quality of the development through the introduction of appropriate landscape to the open spaces.

The green-blue corridor in Kwasa Damansara Master Plan extends throughout the entire township. Figure 13 shows the preliminary design concept (known as greenblue corridor concept) based on the proposed integrated 
stormwater master plan. The proposed stormwater facilities are to be blended with the proposed landscape features to create an ecological park. The main intention in creating and upgrading this particular green area, is to provide multi used facilities and amenities for the public, as well as the residence nearby, for leisure purposes. Landscape park developed surrounding a detention pond will be designed to create a comfortable and pleasant environment, integrated as visual which suitable for beneficial and recreational activities. The functions of the green and blue corridor are as follow:-

- Provide connectivity to major community facilities and assets such as parks, neighbourhoods, points of interest and activity centres

- Offer an alternative means of movement to promote healthy lifestyle and reduction of carbon emission in the township

- $\quad$ Provide an opportunity to experience and enjoy the outdoor

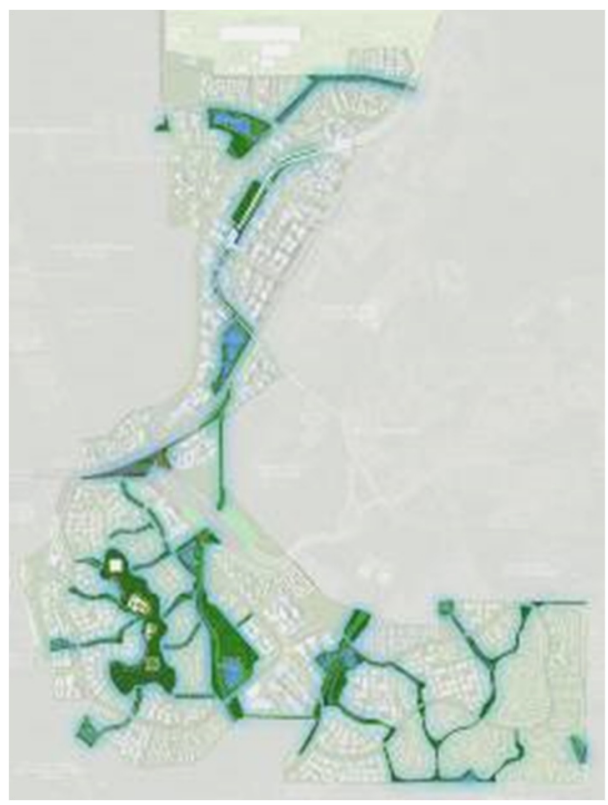

Figure 13. Proposed green-blue corridor for the township.

\section{Conclusions}

The primary goal of the integrated stormwater management and drainage master plan was to minimise the impact of urbanisation to the stormwater environment and to strike a balance between social, economic and environmental concerns to achieve a sustainable development. With the implementation of MSMA and DID Manual incorporating the latest development in stormwater management that is known as control-at-source and treatment train approach, the quality and quantity of the runoff from developing area can be maintained to be the same as pre-development condition. Hence, Kwasa Damansara is aspired to become a model township in Malaysia and on its way to achieving the targets set earlier with three visions of being green, inclusive and connected, by implements a number of solutions to address the issues of cities today.

\section{Acknowledgments}

The authors would like to acknowledge the financial assistance from Ministry of Education under HICoE's niche area Sustainable Urban Stormwater Management (Grant No. 311.PREDAC.4403901).

\section{References}

1. Department of Irrigation and Drainage or DID, Urban Stormwater Management Manual for Malaysia (MSMA). (DID, Kuala Lumpur, 2000).

2. Departments of Irrigation and Drainage or DID. Urban Stormwater Management Manual, 2nd Edition. (Ministry of Natural Resources and Environment Malaysia, Kuala Lumpur. 2011).

3. Zakaria, N.A., Ab. Ghani, A., Abdullah, R., Mohd Sidek, L. \& Ainan, A., Bio-Ecological Drainage System (BIOECODS) For Water Quantity And Quality Control, International Journal River Basin Management, 1(3), 237-251, (2003).

4. A. Ab. Ghani, N.A. Zakaria, R. Abdullah, M. F. Yusof, L. Mohd Sidek, A.H. Kassim \& A. Ainan, BIO-Ecological Drainage System (BIOECODS): Concept, Design and Construction. in Proc. of The $6^{\text {th }}$ International Conference on Hydroscience and Engineering (ICHE-2004), Brisbane, Australia. (2004).

5. A. Ab. Ghani, N.A. Zakaria, C.K. Chang, \& A. Ainan, Sustainable Urban Drainage System (SUDS) - Malaysian Experiences, in Proc. of 11th International Conference on Urban Drainage, Edinburgh, UK. (2008).

6. N.A. Zakaria, A. Ab. Ghani, T.L. Lau \& C.S. Leow, Securing Water for Future Generations through Sustainable Urban Drainage Designs: A Peek into the Bio-ecological Drainage System (BIOECODS), in Proc. of $3^{\text {rd }}$ International Conference on Managing Rivers in 21st Century: Sustainable Solutions for Global Crisis of Flooding, Pollution and Water Scarcity (Rivers 2011), Penang, Malaysia, (2011).

7. N.A. Zakaria, A. Ab. Ghani, C.K. Chang, BioEcological Drainage Systems (BIOECODS) An Alternative Sustainable Approach To Overcome Water Related Issues, Hydrolink, No.2, 42-43. (2017).

8. Departments of Irrigation and Drainage or DID. DID Manual. Vol.2: River management. (Ministry of Natural Resources and Environment Malaysia, Kuala Lumpur. 2009).

9. Knox County. Knox County Tennessee Stormwater Management Manual. Volume 2 (Technical Guidance). Tennessee, USA. (2008).

10. M.L. Mohd Noh, M.R. Othman, N. Hashim, H. Abu Hashim, N.A. Zakaria \& C.K. Chang Sustainable Urban Stormwater Management Towards Achieving 
The New Urban Agenda for Sustainable Development. in Proc. of 37th IAHR World Congress-Managing Water for Sustainable Development - Learning from the Past for the Future, Kuala Lumpur, Malaysia. 13 - 18 August. 4222-4231. (2017).

11. W. Lacerda, M. Ehrlich, S.A. Fontoura, \& A.S. Sayão, Landslides: Evaluation and Stabilization /Glissement de Terrain: Evaluation et Stabilisation. (2004).

12. C.K. Chang, N.A. Zakaria, N.A. Alias, H. Abu Hashim \& S.H. Gan. Sustainable Solutions to River Improvement Works Using Bio-Engineering Technique. in Proc. of 21st Congress of International Association for Hydro-Environment Engineering and Research (IAHR), Asia Pacific Division (APD) - Multi-perspective Water for Sustainable Development, Yogyakarta, Indonesia. 2 - 5 September. 1461-1467. (2018). 